\title{
Development of a New Murine Model of Type 2 Autoimmune Hepatitis Using a Human Liver Protein
}

\author{
Pablo Thomas-Dupont, ${ }^{*}$ Peter Grube-Pagola, ${ }^{*}$ Irma Y. Izaguirre-Hernández, ${ }^{*}$ Karina G. Hernández-Flores, ${ }^{*}$ \\ Elvis E. Sánchez-Marce, ${ }^{\dagger}$ Ana D. Cano-Contreras, ${ }^{*}$ José M. Remes-Troche, ${ }^{*}$ and Héctor Vivanco-Cid*
}

From the Instituto de Investigaciones Medico-Biológicas, * Universidad Veracruzana, Veracruz, México; and the Hospital Regional de Alta Especialidad de Veracruz, ${ }^{\dagger}$ Servicios de Salud de Veracruz, Veracruz, México

\author{
Accepted for publication \\ October 4, 2021. \\ Address correspondence to \\ Héctor Vivanco-Cid, Ph.D. \\ Instituto de Investigaciones \\ Medico-Biológicas, Uni- \\ versidad Veracruzana, Avenida \\ Iturbide S/N, Col. Centro, \\ Veracruz C.P. 91700 , Méx- \\ ico. E-mail: hvivanco@uv.mx.
}

\begin{abstract}
Autoimmune hepatitis (AIH) is a chronic inflammatory condition of the liver characterized by parenchymal destruction, hypergammaglobulinemia, specific autoantibody production, and hepatic fibrosis and necrosis. Murine models of AIH have been described; however, little is known about the immunologic mechanisms of tissue destruction. In this study, a new murine model of type 2 AIH was developed using recombinant human cytochrome P450 (CYP) 2D6 emulsified with complete Freund's adjuvant (CFA). BALB/c mice were immunized with $2 \mu \mathrm{g} / \mathrm{mL}$ i.p. of CYP2D6 in CFA. The control group received CFA or phosphate-buffered saline alone. Alanine aminotransferase activity, autoantibody production, IgG concentrations, histologic damage, and specific T-cell response were evaluated. Persistent $\mathrm{AIH}$, characterized by cellular infiltration, hepatic fibrosis, elevated alanine aminotransferase, and the production of anti-liver kidney microsomal antibody type 1 developed in CFA/CYP2D6immunized mice. These mice presented high levels of $\operatorname{IgG}$ and its subclasses $\operatorname{IgG1}, \operatorname{IgG} 2 \mathrm{a}$, and IgG2b against liver self-proteins. Interestingly, $\mathrm{IL}^{+} 2^{+}$and interferon $\gamma$-positive Cyp2d6-specific T cells were present in greater concentrations in mice immunized with CFA/CYP2D6 compared with control. Immunization with CFA, in combination with a natural human autoantigen like CYP2D6, was demonstrated to break tolerance, resulting in a chronic form of autoimmune-related liver damage. This murine model of type $2 \mathrm{AIH}$ is expected to be instrumental in understanding the immunologic mechanisms of the pathogenesis of this autoimmune liver disease. (Am J Pathol 2022, 192: 21-30; https://doi.org/ 10.1016/j.ajpath.2021.10.006)
\end{abstract}

Autoimmune hepatitis (AIH) is a chronic inflammatory liver disorder of unknown etiology, characterized by an immunologic intolerance to hepatic components, that progressively destroys the hepatic parenchyma. Clinical manifestation is commonly characterized by hypergammaglobulinemia, interface hepatitis, aminotransferase elevation, and serum autoantibodies. ${ }^{1,2}$ Two types of AIH-type 1 and type 2-are recognized based on the autoantibody profile of serum samples. Type $1 \mathrm{AIH}$ is defined by seropositivity for anti-nuclear antibodies and/or anti-smooth muscle antibodies, whereas type $2 \mathrm{AIH}$ is characterized by high levels of anti-liver kidney microsomal type 1 antibody (anti-LKM-1) and/or anti-liver cytosol type 1 antibody. ${ }^{3-5}$ The targets of these antibodies are the cytochrome P450 (CYP) 2D6 isozyme ${ }^{6}$ and formiminotransferase cyclodeaminase (FTCD), ${ }^{7}$ respectively. These enzymes are expressed in hepatocytes, and a previous report demonstrated correlation between the levels of antibodies and AIH activity. ${ }^{8}$ To date, the etiology and pathogenesis of this liver disease are unknown, and more information is needed to clarify which immune mechanism is involved in the pathogenesis of AIH. For this reason, several animal models of liver inflammation have been developed, including transgenic and nontransgenic models,

Supported by Sectorial en Investigación Básica SEP-CONACyT project 256235 and Fronteras de la ciencia project 1192 (H.V-C.).

Disclosures: None declared. 
which are expected to be useful in the identification of mechanisms of the loss of immunologic tolerance.

Complete Freund's adjuvant (CFA), commonly used in research, acts by prolonging the lifespan of injected autoantigen by stimulating its effective delivery to the immune system, and by providing a complex set of signals to the innate compartment of the immune system, resulting in altered leukocyte proliferation and differentiation. ${ }^{9}$ The use of CFA is necessary for the induction of many experimental models of autoimmune diseases, such as experimental autoimmune encephalomyelitis, neuritis, uveitis, thyroiditis, and orchitis. ${ }^{10-14}$ Because of its capacity to stimulate cellular and humoral immune responses, CFA has been used to develop animal models that mimic the liver damage caused by the immune system in patients with autoimmune liver diseases. ${ }^{15,16}$ However, these models have limitations, and more information is necessary for understanding the immune mechanism of this disease. Here, a new murine model was generated using recombinant CYP2D6, a human liver protein target of anti-LKM-1 antibodies, combined with CFA.

\section{Materials and Methods}

\section{Animals and Immunization}

Four- to six-week-old female mice of the BALB/c strain were purchased from Universidad Nacional Autónoma de Mexico (Mexico City, Mexico). Animals were housed in a 12-hour light/dark cycle with a constant-temperature environment of $22^{\circ} \mathrm{C}$, and a standard diet and water were supplied ad libitum. A group of 20 mice were immunized with $2 \mu \mathrm{g} / \mathrm{mL}$ i.p. of recombinant human CYP2D6 (SigmaAldrich, St. Louis, MO) in $200 \mu \mathrm{L}$ of emulsion with $1 \mathrm{~mL}$ of CFA (Sigma-Aldrich) and $1 \mathrm{~mL}$ of sterile phosphatebuffered saline (PBS; $1.5 \mathrm{mmol} / \mathrm{L} \quad \mathrm{KH}_{2} \mathrm{PO}_{4}, 8 \mathrm{mmol} / \mathrm{L}$ $\left.\mathrm{Na}_{2} \mathrm{HPO}_{4}, 2.7 \mathrm{mmol} / \mathrm{L} \mathrm{KCl}, 137 \mathrm{mmol} / \mathrm{L} \mathrm{NaCl}\right)$. As controls, 20 animals received $200 \mu \mathrm{L}$ of the emulsion with $1 \mathrm{~mL}$ of CFA and $1 \mathrm{~mL}$ of sterile PBS (active control), and 20 other animals received only $200 \mu \mathrm{L}$ of sterile PBS (control). Immunizations were done with a primary and a booster dose, separated by 15 days (Figure 1). The study was conducted according to the guidelines of the Declaration of Helsinki and approved by an independent institutional review board (Instituto de Investigaciones Médico Biológicas, number IIMB-18-009-15).

\section{Preparation of Murine Liver Homogenate}

BALB/c normal murine liver samples were homogenized with a tissue grinder in 3 to $6 \mathrm{~mL}$ of PBS. The crude homogenate was centrifuged at $7250 \times g$ for 30 minutes at $4{ }^{\circ} \mathrm{C}$. The supernatant was carefully removed and saved, and the pellet was homogenized with 2 volumes ( 2 to $4 \mathrm{~mL}$ ) of PBS and centrifuged at $7700 \times g$ for 30 minutes at $4{ }^{\circ} \mathrm{C}$. The supernatants were pooled, and then $10 \mu \mathrm{L}$ of $800 \mathrm{mmol} / \mathrm{L}$
$\mathrm{CaCl}_{2}$ solution per milliliter of supernatant was added. The supernatant was mixed for 15 to 30 minutes and centrifuged at $4^{\circ} \mathrm{C}$ for 60 minutes at $16,000 \times g$. The supernatant was saved in a new sterile conic tube and analyzed by SDSPAGE. The total protein from the liver supernatant was measured by a bicinchoninic acid protein assay kit (Thermo Fisher Scientific, Waltham, MA) according to the manufacturer's instructions.

\section{Western Blot Analysis}

Proteins (100 $\mu \mathrm{g}$ of murine liver homogenate) were separated by electrophoresis on 10\% SDS-PAGE and transferred to polyvinylidene difluoride membrane (Merck-Millipore, Burlington, MA). The membrane was blocked overnight with $5 \%$ powdered milk in $0.05 \%$ Tween 20 in PBS at $4^{\circ} \mathrm{C}$. The polyvinylidene difluoride membrane was incubated for 1 hour at room temperature with the mice serum diluted to 1:100 in $0.05 \%$ Tween 20 in PBS/5\% powdered milk. The secondary antibody (goat anti-mouse $\mathrm{IgG}$ ) was conjugated to horseradish peroxidase (Invitrogen, Camarillo, CA), diluted to $1: 1000$ in $0.05 \%$ Tween 20 in $\mathrm{PBS} / 5 \%$ powdered milk. Bound peroxidase was detected with chemiluminescence blot analysis substrate (Bio-Rad, Hercules, $\mathrm{CA}$ ) according to the manufacturer's instructions.

\section{Enzyme-Linked Immunosorbent Assay}

Microwell plates were coated with $5 \mu \mathrm{g} /$ well of CYP2D6 human recombinant protein overnight at $4^{\circ} \mathrm{C}$. After blocking with $0.5 \%$ bovine serum albumin for 1 hour at $37^{\circ} \mathrm{C}$, murine serum samples were serially diluted into the wells and incubated for 2 hours at $37^{\circ} \mathrm{C}$. Plates were washed and a secondary antibody (goat anti-mouse $\mathrm{IgG}, \mathrm{IgG} 1, \mathrm{IgG} 2 \mathrm{a}$, and $\operatorname{IgG} 2 \mathrm{~b}$, all conjugated with horseradish peroxidase; Jackson ImmunoResearch, West Grove, PA) was added to each corresponding well and incubated for 1 hour at $37^{\circ} \mathrm{C}$. The peroxidase reaction was developed by incubation with $2,2^{\prime}$ azino-bis(3-ethylbenzothiazoline-6-sulphonic acid) (SigmaAldrich). End point levels were calculated through linear regression equations as the reciprocal of the serum dilutions that produced OD405 $\mathrm{nm}$ values of 0.2 above the blank, and the levels were reported in enzyme-linked immunosorbent assay units $(\mathrm{EU} / \mathrm{mL})$.

\section{Histologic Examination}

Liver samples were obtained for histologic examination 1 to 6 months after the last immunization. The liver samples were fixed in $10 \%$ formalin, dehydrated, embedded in paraffin, sectioned in 4- $\mu \mathrm{m}$ slides, and stained with hematoxylin and eosin. Various organs (spleen, kidney, lung, and pancreas) were histopathologically examined for extrahepatic inflammation. The sections were subsequently scored for inflammation and injury as previously described ${ }^{17,18}$ (grades: 0, no inflammation or necrosis; 1, minor lobular 


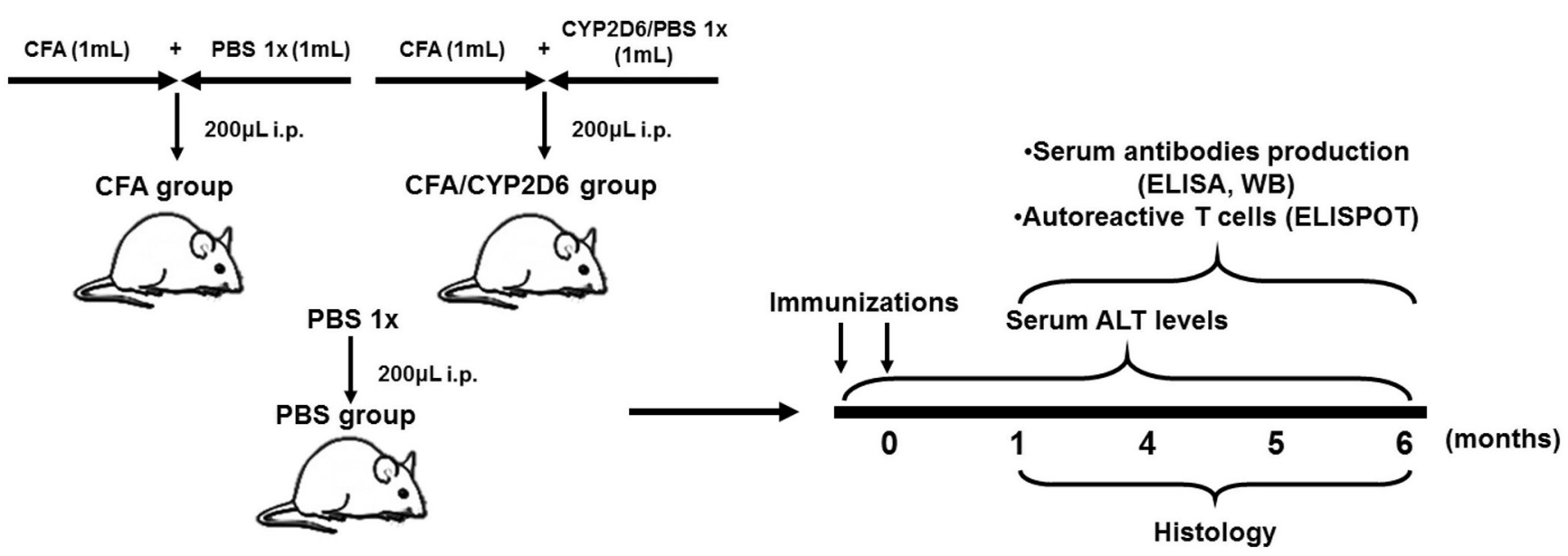

20 mice per group (5 mice per month)

Figure 1 Immunization protocol. Female BALB/c mice aged 4 to 6 weeks were injected i.p. with CFA, CFA/CYP2D6, or PBS twice with a 15-day interval. Blood specimens were collected 0 to 6 months after the second injection, and mice were euthanized 1, 4, 5, and 6 months after the second immunization. ALT, alanine aminotransferase; ELISA, enzyme-linked immunosorbent assay; WB, Western blot.

inflammation with no necrosis; 2, lobular inflammation involving $<50 \%$ of the section; 3, lobular inflammation involving $\geq 50 \%$ of the section; and 4 , inflammation with necrosis). Slides treated with trichrome staining for collagen deposition were analyzed for the presence or absence of fibrosis.

\section{Biochemistry Analysis}

Biochemistry studies to determine the levels of alanine aminotransferase (ALT) in the serum of the mice were performed using a commercial chemistry systems kit (Bayer Healthcare, Leverkusen, Germany) 1 to 6 months after the last immunization.

\section{ELISpot Analysis}

Enzyme-linked immunosorbent spot (ELISpot) assays were performed using a commercial kit (Thermo Fisher Scientific) according to the manufacturer's instructions. Briefly, a 96-well polyvinylidene difluoride membrane ELISpot plate (Merck-Millipore, Burlington, MA) was coated with antimouse IL-2, interferon (IFN)- $\gamma$, and IL-17A overnight at $4^{\circ} \mathrm{C}$ and was then blocked for 2 hours at room temperature with RPMI-1640 medium (Sigma-Aldrich) and supplemented with $10 \%$ fetal bovine serum (Biowest, Riverside, MO) and $1 \%$ antibiotic/antimycotic (Sigma-Aldrich). Spleens were removed from CFA- or CFA/CYP2D6injected mice, placed into RPMI-1640 medium, and passed through a $75-\mu \mathrm{m}$ filter. To prepare the splenocytes, red blood cells were lysed with ammonium-chloride-potassium buffer. Cells were suspended in RPMI-1640 and $5 \times 10^{6}$ cells $/ \mathrm{mL}$ splenocytes were added in duplicate, activated with $2 \mu \mathrm{g} / \mathrm{mL}$ of CYP2D6 human recombinant protein, and incubated for 24 hours at $37^{\circ} \mathrm{C}$ in $5 \% \mathrm{CO}_{2}$. Biotinylated anti-mouse IL-2, IFN- $\gamma$, and IL-17A were added and plates were incubated for 2 hours at $37^{\circ} \mathrm{C}$. Horseradish peroxidase-conjugated Avidin D was added for 45 minutes at room temperature, and the reaction was developed by the addition of 3-amino-9-ethylcarbazole (Sigma-Aldrich).

\section{Adoptive Transfer}

Adoptive transfer was performed as previously described. ${ }^{16}$ Briefly, the spleens of the female BALB/c mice were taken 1 month after the second immunization with $2 \mu \mathrm{g} / \mathrm{mL}$ i.p. of human CYP2D6 in CFA or CFA only. Splenocytes were suspended at $5 \times 10^{6}$ cells $/ \mathrm{mL}$ and stimulated for 48 hours with $1.25 \mu \mathrm{g} / \mathrm{mL}$ of the T-cell mitogen concanavalin (Con) A (Sigma-Aldrich) in RPMI-1640 medium. Con A-activated splenocytes $\left(1 \times 10^{6}\right.$ cells $\left./ \mathrm{mL}\right)$ were injected i.p. into naive 6-week-old BALB/c mice. Control mice received the same number of naive Con $\mathrm{A}$-activated splenocytes. Liver specimens were histologically examined 1 month after passive transfer and stained with hematoxylin and eosin.

\section{Statistical Analysis}

The Tukey multiple-comparisons test was used for determining the significance of differences between more than two groups. A $P$ value of $<0.05$ was considered statistically significant. The data were generated using GraphPad Prism statistical software version 6.01 (GraphPad, San Diego, CA) and are expressed as means \pm SEM.

\section{Results}

\section{Alanine Aminotransferase Activity}

ALT is a clinical marker of hepatic damage commonly used to monitor disease activity. ${ }^{19}$ Therefore, serum ALT levels 
were evaluated in the CFA/CYP2D6-immunized mice and control groups (CFA or PBS). As opposed to the other two groups, the CFA/CYP2D6-immunized mice showed an abnormal ALT level by 4 months after immunization (mean, $77.8 \mathrm{U} / \mathrm{L}$ ), which increased in subsequent months (means, 84.2 and $55.8 \mathrm{U} / \mathrm{L}$ at 5 and 6 months, respectively). The CFA group showed a moderate elevation in ALT level at months 1 and 4 (means, 50.8 and $63 \mathrm{U} / \mathrm{L}$ ); however, these levels presented a tendency to normalize at months 5 and 6 (means, 59.9 and 42.8 U/L). The PBS group showed normal ALT, considered as nonresponse (Figure 2).

\section{B-Cell Response}

The role of autoreactive B cells in AIH involves different mechanisms of action, mainly the well-established secretion of autoantibodies. ${ }^{20}$ To evaluate the B-cell response, levels of total $\mathrm{IgG}$ against the recombinant human CYP2D6 protein were measured in serum samples from CFA- and CFA/CYP2D6-injected mice each month during the study. Total IgG anti-LKM-1 levels were elevated at 1 month after the second immunization in the CFA/CYP2D6 group (mean, 26,839.30 EU/mL), and levels of these antibodies were high in the subsequent months (means, 2844.28, 3050.70, and $3180.13 \mathrm{EU} / \mathrm{mL}$ at 4,5 , and 6 months, respectively). Levels of antibodies in sera from CFA-immunized mice were low (Figure 3A). To further characterize the B-cell response, levels of IgG subclasses were determined. The CFA/CYP2D6-immunized group showed high IgG1 at 1 month after immunization, which was maintained throughout the 6-month study (means, 5008.90, 3468.40, 4069.98, and $4442.63 \mathrm{EU} / \mathrm{mL}$ at $1,4,5$, and 6 months). IgG1 was low in the CFA-immunized group (Figure 3B). Antibodies of the $\mathrm{IgG} 2$ subclasses (IgG2a and $\operatorname{IgG} 2 \mathrm{~b}$ ) were evaluated. As expected, levels of $\operatorname{IgG} 2 \mathrm{a}$ and $\operatorname{IgG} 2 \mathrm{~b}$ antibodies were higher in the CFA/ CYP2D6-immunized group than in the CFA-immunized group (Figure 3, C and D). To evaluate the presence of autoantibodies, serum samples from each group of mice were tested against proteins from BALB/c murine liver homogenate in a Western blot analysis. The serum samples from the CFA/CYP2D6-immunized group contained a 48$\mathrm{kDa}$ protein; this molecular weight corresponds to the murine Cyp from the 2d subfamily, Cyp2d9 (Figure 4).

\section{Histologic Characteristics}

Mice were sacrificed at $1,4,5$, and 6 months after the second injection of CFA/CYP2D6, CFA alone, or PBS. The liver, lung, spleen, kidney, and pancreas were obtained for histologic examination. The livers of PBSinjected mice did not show any histologic changes in any month during the study. CFA-injected mice showed a slight portal tract lymphocytic infiltrate by 1 and 4 months after the second immunization, and normal histologic examination in the subsequent months. CFA/CYP2D6-

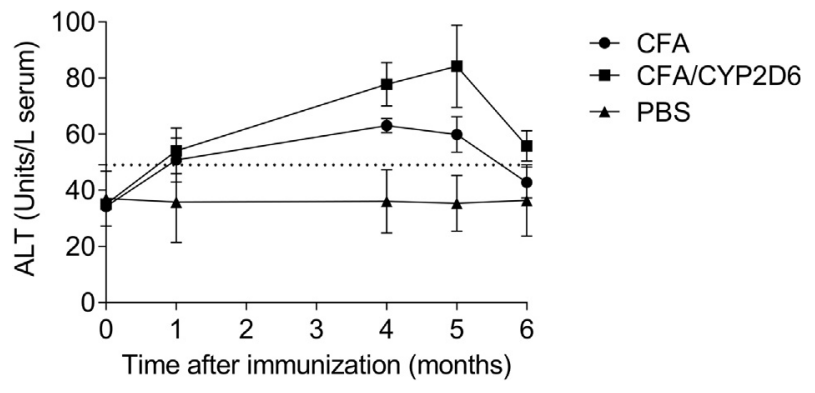

Figure 2 Serum ALT levels in CFA-, CFA/CYP2D6-, and PBS-injected mice. Mice immunized with CFA present elevated serum ALT levels at the 4th month, with a tendency to normalize in the 5th or 6th month after the last immunization. A trend toward elevated serum ALT levels at the 4th, 5th, and 6th months after the second immunization is observed in mice immunized with CFA/CYP2D6. Mice injected with PBS show no increase in ALT level. The dotted line represents the normal value of the test. Data are expressed as means \pm SEM. $n=5$ mice per group.

injected mice showed an intense portal tract lymphoplasmacytic inflammatory infiltrate and interface hepatitis (Figure 5). The other organs showed no histologic changes (data not shown). To determine whether the cellular inflammatory infiltrate causes liver damage, hepatic fibrosis formation was characterized at 6 months after the second immunization in the CFA- and CFA/CYP2D6-immunized mice. The administration of CFA was not associated with an accumulation of collagen in the portal tract. In contrast, mice immunized with CFA/CYP2D6 showed a collagen deposition in the portal tract that extended into the lobule (Figure 6).

\section{T-Cell Response}

The cellular response plays a central role in the pathogenesis of many autoimmune diseases. Research has shown that autoreactive $\mathrm{T}$ cells have a crucial role in the development and establishment of autoimmune diseases. ${ }^{21,22}$ To assess the T-cell response, total splenocytes were isolated from the spleens of CFA/CYP2D6- and CFA-immunized mice, and their response to recombinant human CYP2D6 protein was measured. CFA/CYP2D6-immunized mice presented a response mainly by $\mathrm{IL}-2^{+} / \mathrm{IFN}-\gamma^{+} \mathrm{T}$ cells compared with CFA-immunized mice (Figure 7). To confirm that these lymphocytes were autoreactive, total splenocytes from animals sacrificed 1 month after the second i.p. immunization with $2 \mu \mathrm{g} / \mathrm{mL}$ of human CFA/CYP2D6 or CFA only were stimulated over 48 hours with Con A and transferred into wild-type recipient mice, and their autoreactivity response was measured by histologic examination, ALT and aspartate aminotransferase (AST) activity, and the presence of autoantibodies 1 month after the adoptive transfer. Figure 7 shows the results of the adoptive transfer experiment. The CFA/CYP2D6-recipient animals showed high ALT and AST levels (means, 56.20 and $96.40 \mathrm{U} / \mathrm{L}$, respectively), 

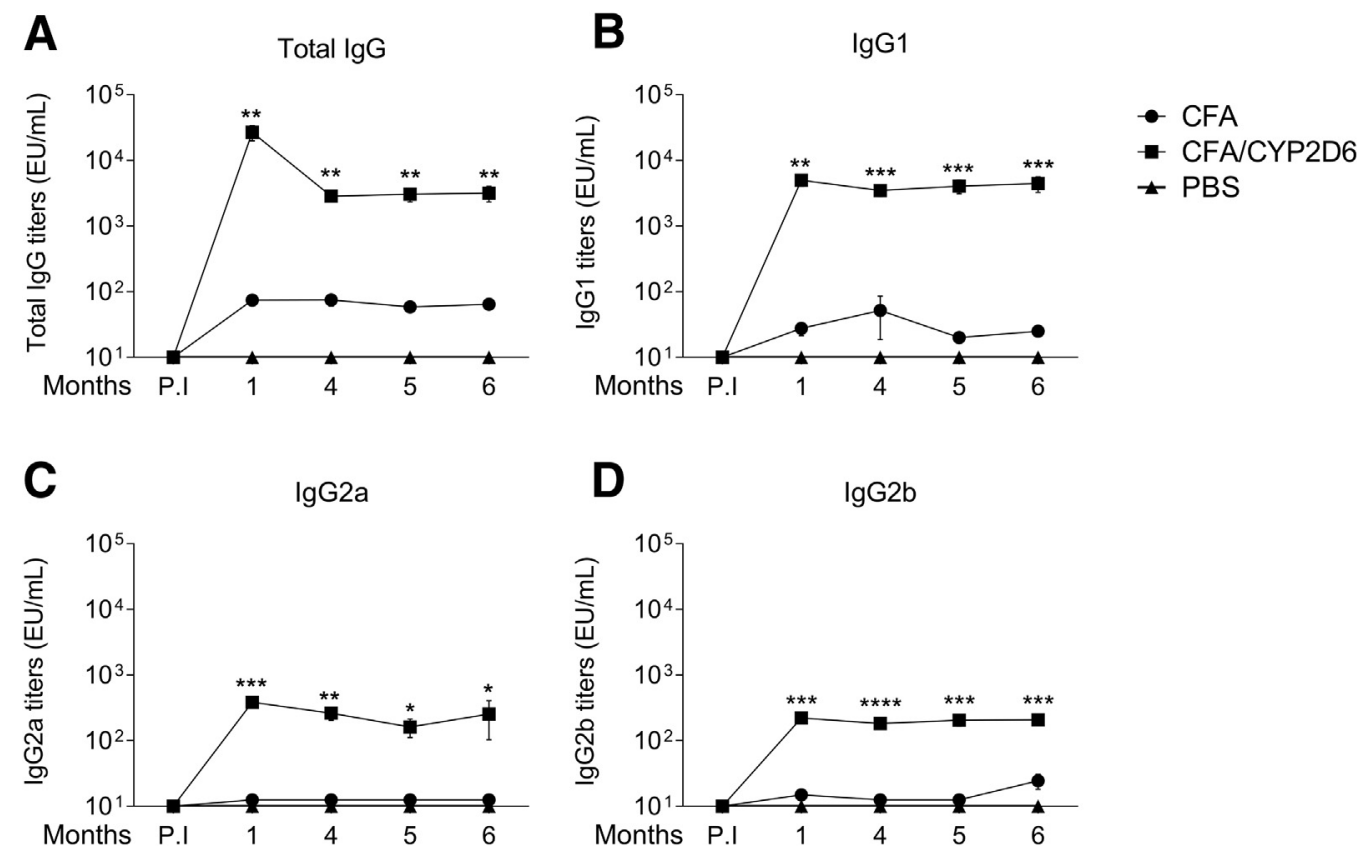

Figure 3 Anti-liver kidney microsomal type 1 antibody (anti-LKM-1) concentrations. CFA/CYP2D6-immunized mice show elevated levels of total IgG (A) and IgG1 (B), IgG2a (C), and IgG2b (D) subclasses of anti-LKM-1 antibodies compared with CFA-immunized mice or PBS-injected mice. Data are expressed as means \pm SEM $\left[\right.$ in $\log _{10}$ concentration $\left.(\mathrm{EU} / \mathrm{mL})\right] . n=5$ mice per group. ${ }^{*} P<0.05,{ }^{* *} P<0.01,{ }^{* *} P<0.001$, and ${ }^{* * * * P}<0.0001$ versus CFA (Tukey multiple-comparisons test).

presence of specific autoantibodies against a $48-\mathrm{kDa}$ protein, and mild but distinct histologic changes (Figure 8).

\section{Discussion}

AIH is a complex and multifactorial inflammatory disease of the liver involving interactions between genetic background and environmental and immunologic factors that trigger an inflammatory response through autoreactive $\mathrm{T}$ cells, inducing the progressive destruction of hepatocytes and leading to liver failure if left untreated. Although AIH was described $>50$ years ago by Waldenström, ${ }^{23}$ little is known about how the immune system acts against self-proteins from the liver. This is partly due to the low incidence and

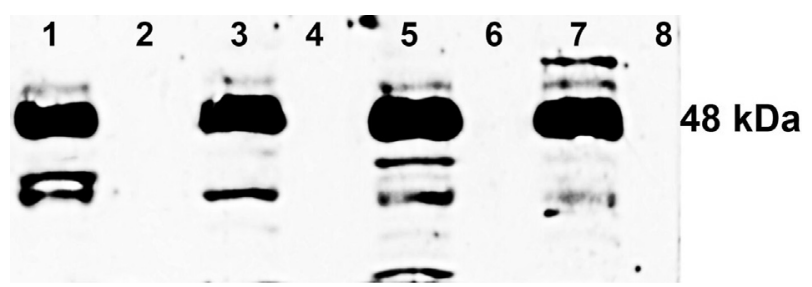

Figure 4 Determination of autoantibodies in mouse serum samples. Serum samples from mice immunized with CFA/CYP2D6 present positivity against 48-kDa protein at the 1st (line 1), 4th (line 3), 5th (line 5), and 6th (line 7) months after the second immunization. Lines 2, 4, 6, and 8 correspond to mice immunized with CFA. The Western blot technique was used to determine the presence of autoantibodies in the serum samples using mouse liver homogenates. prevalence of AIH around the world, hindering basic and clinical studies of the disease. To resolve this problem, for the past 30 years, several animal models have been used to reflect the clinical, biochemical, and histologic pattern of the disease in humans. Each model often reflects a particular aspect of $\mathrm{AIH}$, but one that represents complete disease is lacking.

Here, a new murine model of type $2 \mathrm{AIH}$ was developed using CFA in combination with a natural human autoantigen, CYP2D6. Importantly, new evidence regarding how this immunization can break the immune tolerance against liver self-proteins in a nonpermissive genetic background such as the $\mathrm{BALB} / \mathrm{c}$ strain, resulting in a chronic form of autoimmune liver damage, was presented. In addition, based on the high prevalence of autoimmune disorders associated with sex, the experimental approach used female mice, but not male mice. In particular, in humans, about $70 \%$ to $80 \%$ of AIH patients are women, ${ }^{24,25}$ and in murine models, liver injury has been reported to be more severe in female mice than in male mice. In models of drug-induced liver injury or Con A-induced liver injury, $\mathrm{BALB} / \mathrm{c}$ females develop more severe hepatitis and produce more proinflammatory hepatic cytokines and antibodies than do males. ${ }^{26,27}$ Splenocytes cultured from female mice exhibit fewer T-regulatory cells and higher concentrations of IL- $1 \beta$ and IL- 6 than do those from males. However, Tregulatory cell function does not differ by sex. ${ }^{26}$ Plasma ALT, tumor necrosis factor (TNF)- $\alpha$, and IFN- $\gamma$ levels were significantly higher after Con A administration in females than in males. Furthermore, plasma ALT, TNF- $\alpha$, and IFN- 
A

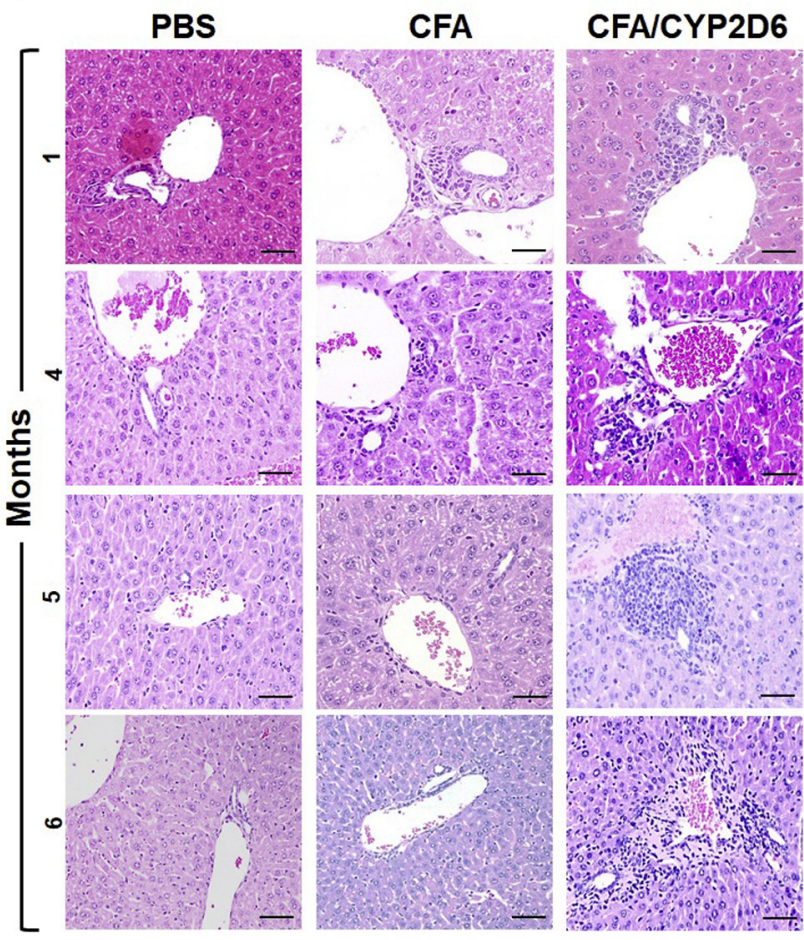

B

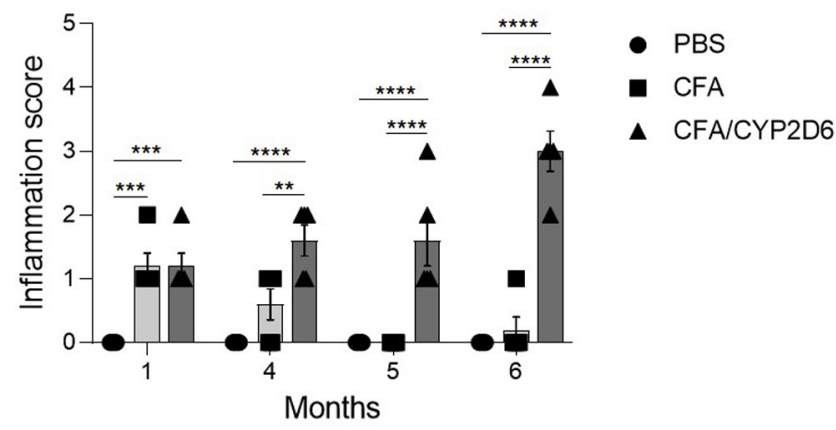

Figure 5 Histologic examination of livers from BALB/C mice injected with CFA, CFA/CYP2D6, or PBS. A: Representative liver sections from CFA-, CFA/ CYP2D6-, and PBS-injected mice. Control mice (PBS) do not show any inflammatory infiltrate. CFA-immunized mice show scarce portal inflammation in the 1st and 4th months and normal histologic examination at the 5th and 6th months after the second immunization. CFA/CYP2D6-immunized mice exhibit portal inflammatory infiltrate at the 1st, 4th, and 5th months. Mice in the 6th month present interface hepatitis. B: Liver inflammation scores in mice injected with PBS, CFA, and CFA/CYP2D6 at the 1st, 4th, 5th, and 6th months after injection. Data are expressed as means \pm SEM. $n=5$ mice per group. ${ }^{* *} P<0.01$, $* * * P<0.001$, and $* * * * P<0.0001$. Scale bars $=100 \mu \mathrm{m}$.

$\gamma$ levels were decreased significantly after ovariectomy. ${ }^{2 \gamma}$ Castrated males developed more severe hepatitis than did intact males in a murine model of drug-induced liver injury. ${ }^{26}$

The possible explanation for this sex-based disparity remains unknown, but it has been theorized that sex hormones have a crucial role in autoimmunity. There is a general consensus to use female over male mice in animal models. While it is true that, in humans, AIH occurs predominantly in women, men have been reported to have a higher relapse rate and a younger age of disease onset. Despite this, men with AIH have significantly greater long-term survival than do women with $\mathrm{AIH} .^{28}$

Consistent with the findings from the present study, other studies have reported that chronic hepatitis is produced by i.p. immunizations with liver proteins in CFA. One study reported extensive periportal infiltration in most mice treated with consecutive i.p. immunizations with allogeneic liver homogenate. In the same study, liver inflammation could be adoptively transferred to syngeneic recipients by splenocytes
CFA
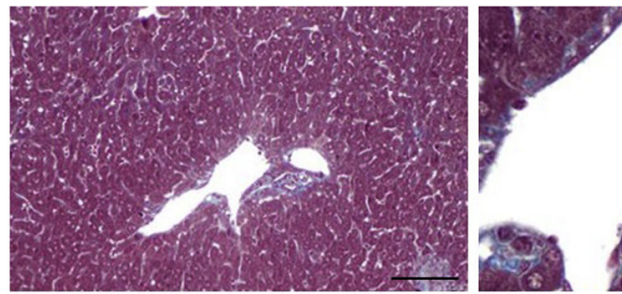

$\mathrm{CFA} /$ CYP2D6

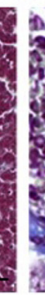

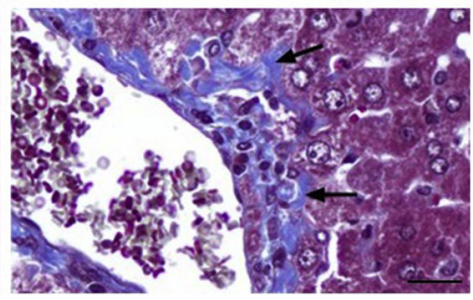

Figure 6 Liver fibrosis after immunization in mice injected with CFA/CYP2D6 but not CFA alone. Representative liver sections from CFA- and CFA/ CYP2D6-injected mice at 6 months after the second immunization (trichrome staining). The liver in CFAimmunized mice does not show the presence of collagen fibers in the portal tract. CFA/CYP2D6immunized mice exhibit the presence of collagen fibers (arrows) in the portal tract that extend into the lobule. Scale bars $=100 \mu \mathrm{m}$. 

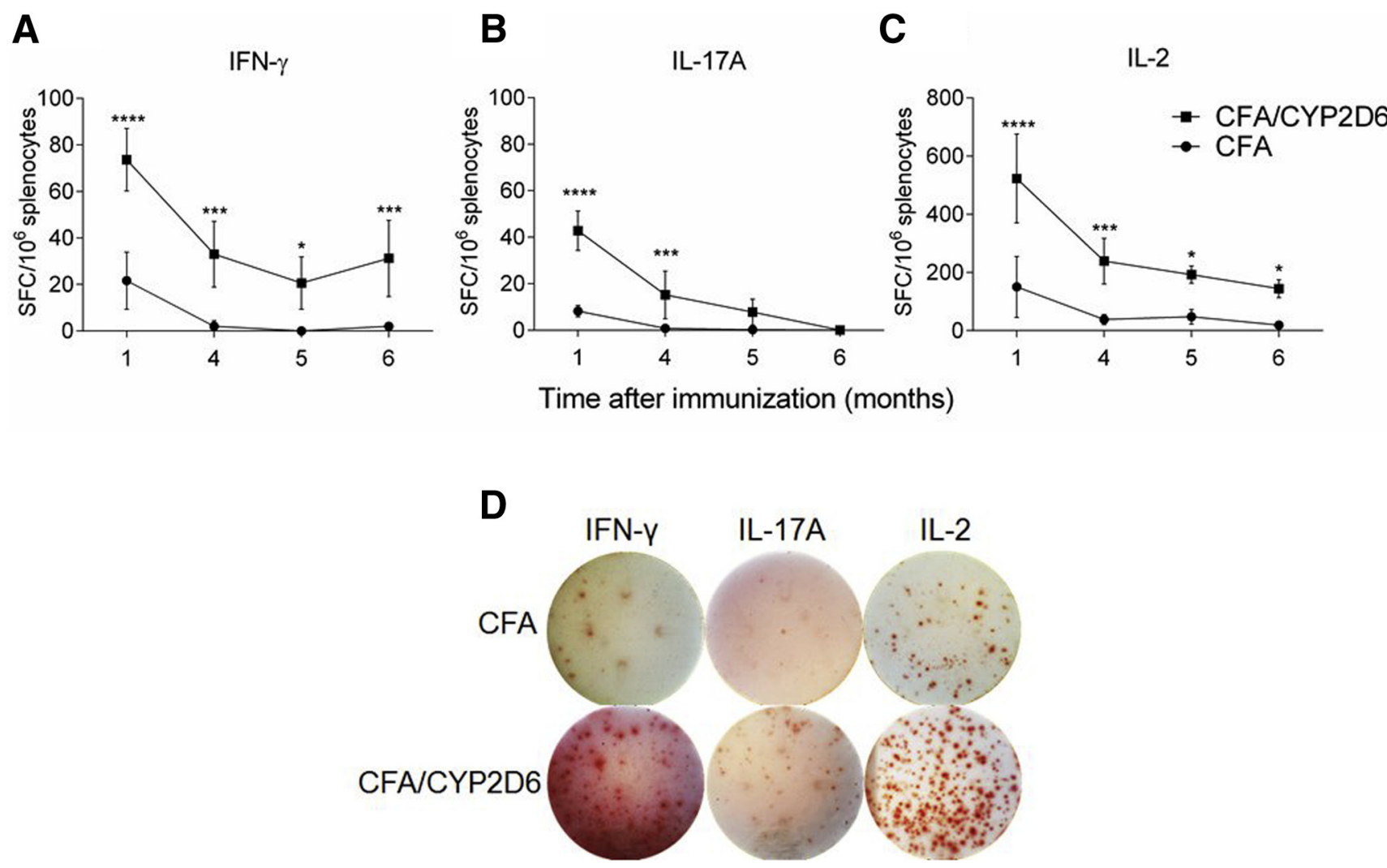

Figure 7 Characterization of the T-cell response. A-C: Frequency of T-cell populations producing IFN- $\gamma(\mathbf{A})$, IL-17A (B), and IL-2 (C) in splenocytes from mice immunized with CFA or CFA/CYP2D6. The splenocytes were obtained at the 1st, 4th, 5th, and 6th months after the last immunization. D: Representative wells of specific T-cell-producing IFN- $\gamma$, IL-17A, and IL-2 from mice immunized with CFA or CFA/CYP2D6. Data are expressed as mean \pm SEM spots-forming cells $(\mathrm{SFC}) / 10^{6}$ splenocytes. $n=5$ mice per group. ${ }^{*} P<0.05,{ }^{* *} P<0.001$, and ${ }^{* * * *} P<0.0001$ versus CFA.

or lymphocytes. ${ }^{29}$ In other work, Lohse et $\mathrm{al}^{16}$ demonstrated that hepatitis was induced for up to 6 months with a single i.p. immunization in C57BL/6 mice with the $100,000 \times g$ supernatants of syngeneic liver homogenate (S-100) in CFA. Additionally, the ALT level was moderately increased. These results are similar to those observed in the present study, in which CFA/CYP2D6-immunized mice presented an increase in ALT level by 4 months after immunization (mean, $77.8 \mathrm{U} /$ L). Interestingly, these levels were elevated in the subsequent months (means, 84.2 and $55.8 \mathrm{U} / \mathrm{L}$ at 5 and 6 months, respectively) (Figure 2). The measurement of ALT in serum is commonly used to evaluate liver damage in AIH patients. AIH may also be identified by recognition of mild to moderate elevations of ALT activity. ${ }^{30}$ Therefore, the results from the present study suggest that this animal group presented progressive hepatic damage that could be comparable to that in human disease.

Elevated serum total $\operatorname{IgG}$ level is another important parameter characteristic of human $\mathrm{AIH}$ and is used as a criterion for its diagnosis. ${ }^{31}$ In the present study, the CFA/ CYP2D6-immunized group showed an elevated IgG level. High serum $\mathrm{IgG}$ levels were mainly of the $\mathrm{IgG} 1$ subclass. Interestingly, the other IgG subclasses, IgG2a and IgG2b, were present in the serum of the CFA/CYP2D6-immunized group (Figure 3). Elevations of these IgG subclasses are representative of a Th1-type response, which has been reported to have a role in complement activation and antibody-dependent cell-mediated immunity. ${ }^{32}$ These results are similar to those reported in another murine model in which the presence of the subclasses $\operatorname{IgG} 2 \mathrm{a}$ and $\operatorname{IgG} 2 \mathrm{~b}$ was observed. ${ }^{33}$ Anti-LKM-1 is known to be present in the serum of patients with type $2 \mathrm{AIH}$ and in a subset of patients with chronic hepatitis $C$. The autoantigen to anti-LKM-1 has been identified to be CYP2D6. ${ }^{34,35}$ In the present experiment, the murine serum samples contained a $48-\mathrm{kDa}$ protein. This molecular weight corresponds to the murine Cyp isozyme from the $2 \mathrm{~d}$ subfamily, Cyp2d9. The foregoing is due to the high amino acid sequence homology between the murine Cyp isozymes Cyp2d9, Cyp2d11, Cyp2d22, and Cyp2d26 and human CYP2D6. ${ }^{36}$ Thus, Cyp2d6-specific B cells react to human CYP2D6 peptides with homology to the murine Cyp isozymes, indicating that molecular mimicry breaks tolerance and subsequently causes severe persistent autoimmune-related liver damage.

Histologic findings of the liver in AIH patients are usually characterized by interface hepatitis mainly composed of mononuclear and plasma cells. ${ }^{25,37}$ Recently, several experimental works have demonstrated that liver-infiltrating T cells from patients with type $2 \mathrm{AIH}$ recognize CYP2D6. ${ }^{22,38}$ Thus, the CYP2D6-specific T-cell response in AIH may contribute to the pathogenesis of the disease. In a recent murine model, CFA/ CYP2D6-immunized mice presented a response mainly by 
A
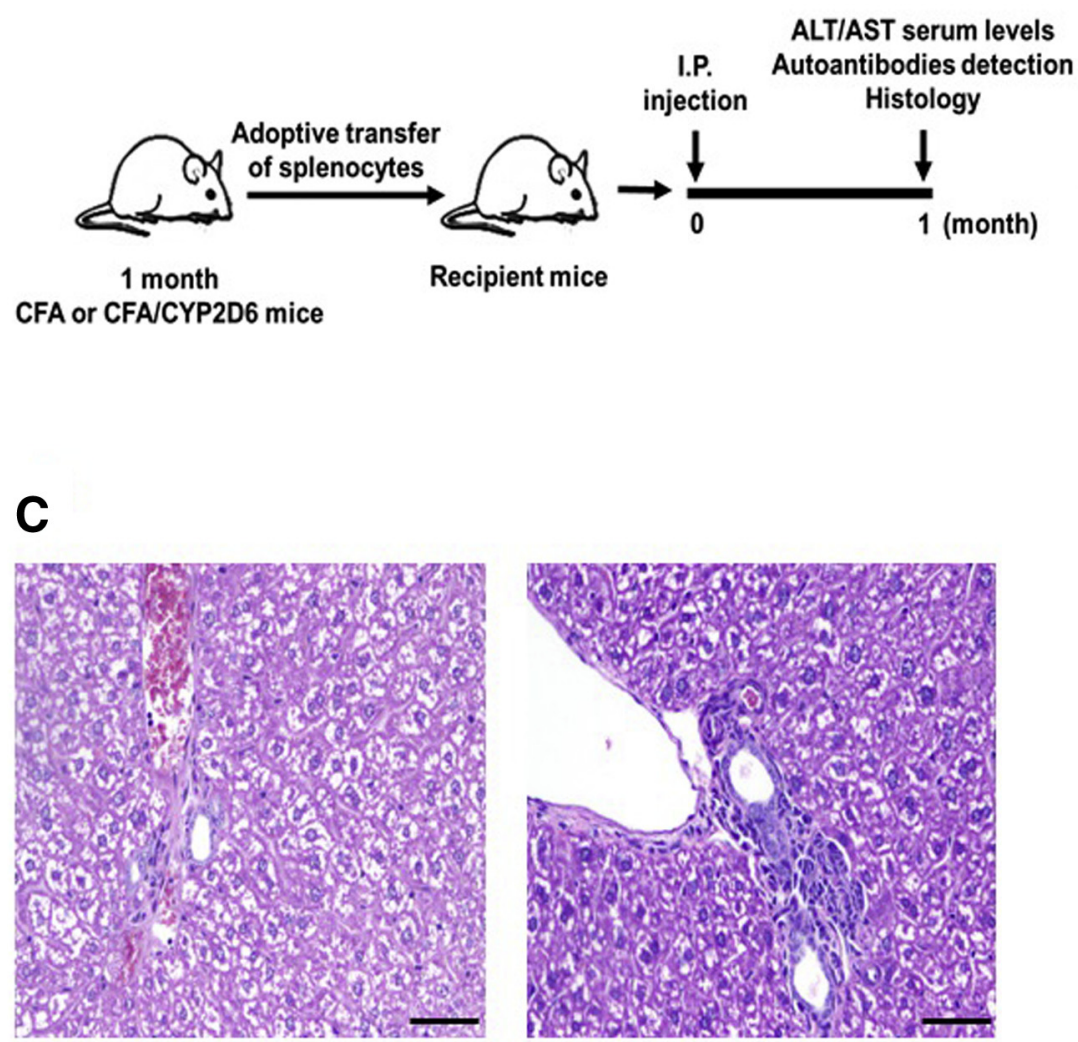

CFA
B

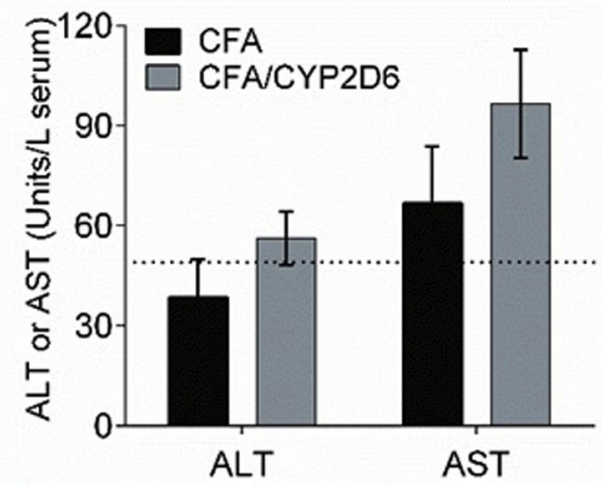

D

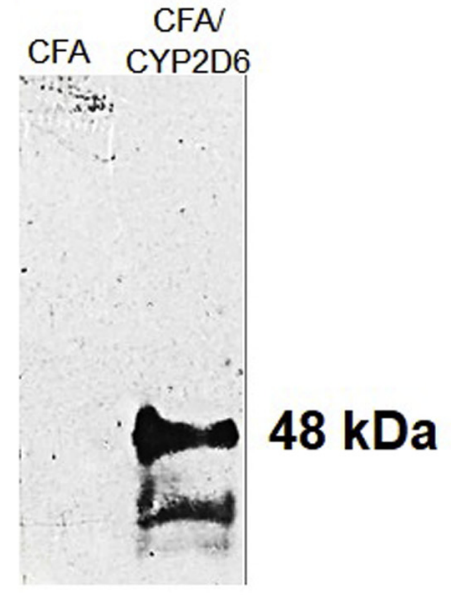

Figure 8 Adoptive transfer. A: The spleen cells to be transferred were obtained 1 month after the second immunization. Serum and liver sections were prepared from recipient mice 1 month after transfer. B: Serum levels of ALT and AST in CFA cells or CFA/CYP2D6 cells from a transferred mouse. The dotted line represents the normal value of the test. C: Hematoxylin and eosin staining of a liver section from a transferred mouse with CFA cells. Note the intact structures of the hepatic parenchyma. A section from a transferred mouse with CFA/CYP2D6 cells. Note the scarce amount of inflammatory cell infiltration in the portal tracts. D: The Western blot technique is used to determine the presence of autoantibodies in the serum samples from mice recipient of CFA cells or CFA/CYP2D6 cells using mouse liver homogenates. Data are expressed as means \pm SEM. $n=5$ mice per group. Scale bars $=50 \mu \mathrm{m}$.

IL- $2^{+} / \mathrm{IFN}-\gamma^{+}$T cells, compared with CFA-immunized mice, in total splenocytes stimulated with recombinant human CYP2D6. Another interesting observation was that these groups of animals presented a characteristic portal and periportal (interface hepatitis) inflammatory infiltrate mainly characterized by lymphocytes, as occurs in human disease. ${ }^{35,36}$ Furthermore, CFA/CYP2D6-immunized mice showed an accumulation of collagen fibers in the portal tract that extended into the lobule at 6 months after the second immunization with the antigen. These results indicate that the presence of a murine Cyp family in the liver plays an important role in the development of chronic hepatic inflammation and fibrosis.

However, some limitations should be noted. First, serum ALT was the only biochemical marker of liver damage that was measured. Although the level of serum ALT activity reflects damage to hepatocytes and is considered to be a highly sensitive and fairly specific preclinical and clinical biomarker of hepatotoxicity, an increase in serum ALT activity level has also been associated with other organ toxicities. ${ }^{39,40}$ To assess the risk for false-positives due to extraneous sources of serum ALT activity, biomarkers in addition to serum ALT activity are sometimes used for determining liver function. ${ }^{41}$

In conclusion, the results of the study in the current model of AIH suggest a loss of tolerance to murine liver proteins, causing with it the development of an autoimmune process. Loss of immunologic tolerance is induced by the molecular mimicry established in the presence of a foreign antigen to conserved regions of murine liver proteins. Therefore, the experimental model developed could be used as an important tool for investigating and characterizing, in additional detail, the immunopathologic mechanisms of loss of tolerance to self-proteins leading to chronic liver parenchymal destruction.

\section{Acknowledgment}

We thank Azucena Venet Alderete-Vázquez for her valuable assistance with the histologic stains. 


\section{Author Contributions}

H.V.-C. conceptualized the study; P.T.-D. and I.Y.I.-H. curated data; P.T.-D., J.M.R.-T., and H.V.-C. formally analyzed data; H.V.-C. acquired funds; H.V.-C. performed investigation; P.T.-D., I.Y.I.-H., K.G.H.-F., E.E.S.-M., A.D.C.-C., and P.G.-P. developed methodology; H.V.-C. performed project administration; H.V.-C. supervised the study; P.T.-D. and H.V.-C. wrote the original draft; P.T.-D., K.G.H.-F., and H.V.-C reviewed and edited the draft; all authors read and agreed to the published version of the manuscript.

\section{References}

1. Krawitt EL: Autoimmune hepatitis. N Engl J Med 2006, 354:54-66

2. Czaja AJ, Freese DK, American Association for the Study of Liver Disease: Diagnosis and treatment of autoimmune hepatitis. Hepatology 2002, 36:479-497

3. Vergani D, Longhi MS, Bogdanos DP, Ma Y, Mieli-Vergani G: Autoimmune hepatitis. Semin Immunopathol 2009, 31:421-435

4. Martini E, Abuaf N, Cavalli F, Durand V, Johanet C, Homberg JC: Antibody to liver cytosol (anti-LC1) in patients with autoimmune chronic active hepatitis type 2. Hepatology 1988, 8:1662-1666

5. Homberg JC, Abuaf N, Bernard O, Islam S, Alvarez F, Khalil SH, Poupon R, Darnis F, Levy VG, Grippon P: Chronic active hepatitis associated with antiliver/kidney microsome antibody type 1: a second type of "autoimmune" hepatitis. Hepatology 1987, 7: $1333-1339$

6. Gueguen M, Meunier-Rotival M, Bernard O, Alvarez F: Anti-liver kidney microsome antibody recognizes a cytochrome P450 from the IID subfamily. J Exp Med 1988, 168:801-806

7. Lapierre P, Hajoui O, Homberg JC, Alvarez F: Formiminotransferase cyclodeaminase is an organ-specific autoantigen recognized by sera of patients with autoimmune hepatitis. Gastroenterology 1999, 116: 643-649

8. Muratori L, Cataleta M, Muratori P, Lenzi M, Bianchi FB: Liver/kidney microsomal antibody type 1 and liver cytosol antibody type 1 concentrations in type 2 autoimmune hepatitis. Gut 1998, 42: $721-726$

9. Billiau A, Matthys P: Modes of action of Freund's adjuvants in experimental models of autoimmune diseases. J Leukoc Biol 2001, 70:849-860

10. Freund J, Stern ER, Pisani TM: Isoallergic encephalomyelitis and radiculitis in guinea pigs after one injection of brain and mycobacteria in water-in-oil emulsion. J Immunol 1947, 57:179-194

11. Gaupp S, Hartung HP, Toyka K, Jung S: Modulation of experimental autoimmune neuritis in Lewis rats by oral application of myelin antigens. J Neuroimmunol 1997, 79:129-137

12. Anke M, Masaoka T, Groppel B, Zervas G, Arnhold W: The influence of sulphur, molybdenum and cadmium exposure on the growth of goat, cattle and pig. Arch Tierernahr 1989, 39:221-228

13. Kong YC: Experimental autoimmune thyroiditis in the mouse. Curr Protoc Immunol 2007. Chapter 15:Unit 157

14. Sato K, Hirokawa K, Hatakeyama S: Experimental allergic orchitis in mice. Histopathological and Immunological studies. Virchows Arch A Pathol Anat Histol 1981, 392:147-158

15. Buschenfelde KH, Kossling FK, Miescher PA: Experimental chronic active hepatitis in rabbits following immunization with human liver proteins. Clin Exp Immunol 1972, 11:99-108

16. Lohse AW, Manns M, Dienes HP, Meyer zum Buschenfelde KH, Cohen IR: Experimental autoimmune hepatitis: disease induction, time course and T-cell reactivity. Hepatology 1990, 11:24-30
17. Chi G, Pei JH, Ma QY, Ru YX, Feng ZH: Chemical induced inflammation of the liver breaks tolerance and results in autoimmune hepatitis in Balb/c mice. Immunol Lett 2020, 218:44-50

18. Thomas D, Wu TY, Cottagiri M, Nyandjo M, Njoku DB: Induction of drug-induced, autoimmune hepatitis in BALB/c mice for the study of its pathogenic mechanisms. J Vis Exp 2020, 159:e59174

19. Feng C, Cao LJ, Song HF, Xu P, Chen H, Xu JC, Zhu XY, Zhang XG, Wang XF: Expression of PD-L1 on $\mathrm{CD} 4+\mathrm{CD} 25+$ Foxp3 + regulatory $\mathrm{T}$ cells of patients with chronic HBV infection and its correlation with clinical parameters. Viral Immunol 2015, 28:418-424

20. Vergani D, Mieli-Vergani G, Mondelli M, Portmann B, Eddleston AL: Immunoglobulin on the surface of isolated hepatocytes is associated with antibody-dependent cell-mediated cytotoxicity and liver damage. Liver 1987, 7:307-315

21. Senaldi G, Portmann B, Mowat AP, Mieli-Vergani G, Vergani D: Immunohistochemical features of the portal tract mononuclear cell infiltrate in chronic aggressive hepatitis. Arch Dis Child 1992, 67: $1447-1453$

22. Lohr H, Manns M, Kyriatsoulis A, Lohse AW, Trautwein C, Meyer zum Buschenfelde KH, Fleischer B: Clonal analysis of liver-infiltrating T cells in patients with LKM-1 antibody-positive autoimmune chronic active hepatitis. Clin Exp Immunol 1991, 84:297-302

23. Waldenstrom J: [Liver, blood proteins and nutritive protein]. Dtsch Z Verdau Stoffwechselkr 1953, 9:113-119

24. Fallatah HI, Akbar HO: Autoimmune hepatitis as a unique form of an autoimmune liver disease: immunological aspects and clinical overview. Autoimmune Dis 2012, 2012:312817

25. Oo YH, Hubscher SG, Adams DH: Autoimmune hepatitis: new paradigms in the pathogenesis, diagnosis, and management. Hepatol Int 2010, 4:475-493

26. Cho J, Kim L, Li Z, Rose NR, Talor MV, Njoku DB: Sex bias in experimental immune-mediated, drug-induced liver injury in BALB/c mice: suggested roles for Tregs, estrogen, and IL-6. PLoS One 2013, 8:e61186

27. Takamoto S, Nakamura K, Yoneda M, Makino I: Gender-related differences in concanavalin A-induced liver injury and cytokine production in mice. Hepatol Res 2003, 27:221-229

28. Al-Chalabi T, Underhill JA, Portmann BC, McFarlane IG, Heneghan MA: Impact of gender on the long-term outcome and survival of patients with autoimmune hepatitis. J Hepatol 2008, 48: 140-147

29. Scheiffarth F, Warnatz H, Mayer K: Studies concerning the importance of mononuclear cells in the development of experimental hepatitis. J Immunol 1967, 98:396-401

30. Kim WR, Flamm SL, Di Bisceglie AM, Bodenheimer HC, Public Policy Committee of the American Association for the Study of Liver Disease: Serum activity of alanine aminotransferase (ALT) as an indicator of health and disease. Hepatology 2008, 47:1363-1370

31. Alvarez F, Berg PA, Bianchi FB, Bianchi L, Burroughs AK, Cancado EL, Chapman RW, Cooksley WG, Czaja AJ, Desmet VJ, Donaldson PT, Eddleston AL, Fainboim L, Heathcote J, Homberg JC, Hoofnagle JH, Kakumu S, Krawitt EL, Mackay IR, MacSween RN, Maddrey WC, Manns MP, McFarlane IG, Meyer zum Buschenfelde KH, Zeniya M: International Autoimmune Hepatitis Group Report: review of criteria for diagnosis of autoimmune hepatitis. J Hepatol 1999, 31:929-938

32. Azeredo da Silveira S, Kikuchi S, Fossati-Jimack L, Moll T, Saito T, Verbeek JS, Botto M, Walport MJ, Carroll M, Izui S: Complement activation selectively potentiates the pathogenicity of the $\operatorname{IgG} 2 \mathrm{~b}$ and IgG3 isotypes of a high affinity anti-erythrocyte autoantibody. J Exp Med 2002, 195:665-672

33. Lapierre P, Djilali-Saiah I, Vitozzi S, Alvarez F: A murine model of type 2 autoimmune hepatitis: xenoimmunization with human antigens. Hepatology 2004, 39:1066-1074

34. Manns MP, Johnson EF, Griffin KJ, Tan EM, Sullivan KF: Major antigen of liver kidney microsomal autoantibodies in idiopathic 
autoimmune hepatitis is cytochrome P450db1. J Clin Invest 1989, 83: $1066-1072$

35. Zanger UM, Hauri HP, Loeper J, Homberg JC, Meyer UA: Antibodies against human cytochrome P-450db1 in autoimmune hepatitis type II. Proc Natl Acad Sci U S A 1988, 85:8256-8260

36. Holdener M, Hintermann E, Bayer M, Rhode A, Rodrigo E, Hintereder G, Johnson EF, Gonzalez FJ, Pfeilschifter J, Manns MP, Herrath M, Christen U: Breaking tolerance to the natural human liver autoantigen cytochrome P450 2D6 by virus infection. J Exp Med 2008, 205:1409-1422

37. Washington MK: Autoimmune liver disease: overlap and outliers. Mod Pathol 2007, 20 Suppl:S15-S30

38. Longhi MS, Hussain MJ, Bogdanos DP, Quaglia A, Mieli-Vergani G, Ma Y, Vergani D: Cytochrome P450IID6-specific CD8 T cell immune responses mirror disease activity in autoimmune hepatitis type 2. Hepatology 2007, 46:472-484

39. Lindblom P, Rafter I, Copley C, Andersson U, Hedberg JJ, Berg AL, Samuelsson A, Hellmold H, Cotgreave I, Glinghammar B: Isoforms of alanine aminotransferases in human tissues and serum-differential tissue expression using novel antibodies. Arch Biochem Biophys 2007, 466:66-77

40. Yang RZ, Blaileanu G, Hansen BC, Shuldiner AR, Gong DW: cDNA cloning, genomic structure, chromosomal mapping, and functional expression of a novel human alanine aminotransferase. Genomics 2002, 79:445-450

41. Ozer J, Ratner M, Shaw M, Bailey W, Schomaker S: The current state of serum biomarkers of hepatotoxicity. Toxicology 2008, 245: 194-205 